\title{
PENGARUH PEMBERIAN JUS MENTIMUN DAN TOMAT TERHADAP KADAR GLUKOSA DARAH POSTPRANDIAL PEREMPUAN OVERWEIGHT DAN OBESITAS
}

\author{
Martha Sri Wulaning Rejeki, Yekti Wirawanni*) \\ Program Studi Ilmu Gizi Fakultas Kedokteran Universitas Diponegoro \\ Jl.Dr.Sutomo No.18, Semarang, Telp (024) 8453708, Email : gizifk@undip.ac.id
}

\begin{abstract}
Background: Overweight and obesity are the risk factor of diabetes mellitus type 2 which caused by insulin retention. Cucumber and tomato are food with low glycemic index and contains high magnesium. The objective of this study was to determine the effect of cucumber and tomato juice on blood glucose postprandial in overweight and obese women.

Method : This study is a true experimental with pre-post test design. The subjects were women student of Nutrition Science Diponegoro University. Sample included 38 women was taken by consecutive sampling and then split into 2 groups by simple random sampling. The intervention group receive $200 \mathrm{ml}$ of cucumber and tomato juice within 7 days while control group was given 0 calorie syrup. Blood glucose postprandial measured before and after the intervention with spectrophotometry method. Subject's dietary intake obtain using food recall 7x24 hours during the intervention. Saphiro-Wilk used to test the normality, while Independent Sample t-Test, Mann-Whitney, Paired t-Test dan Wilcoxon used to do the statistical analysis.

Result : There was a significant decreased of blood glucose postprandial of 3,32 $\pm 1,97 \mathrm{mg} / \mathrm{dl}$. There was a significant difference of blood glucose postprandial between intervention and control group $(p=0,000)$.

Conclusion : There is significant postprandial blood glucose decreased after 7 days treatment with $200 \mathrm{ml}$ of cucumber and tomato juice.

Key word : Cucumber, tomato, blood glucose, overweight and obese woman.
\end{abstract}

\begin{abstract}
ABSTRAK
Latar Belakang : Overweight dan obesitas berisiko tinggi mengalami diabetes melitus tipe 2 yang diawali dengan resistensi insulin. Mentimun dan tomat merupakan salah satu pangan rendah indeks glikemik dan tinggi magnesium. Penelitian ini bertujuan untuk membuktikan pengaruh pemberian jus mentimun dan tomat terhadap kadar glukosa darah postprandial pada perempuan overweight dan obesitas.

Metode : Jenis penelitian adalah true experimental dengan pre-post group design. Subjek penelitian adalah mahasiswi Ilmu Gizi Universitas Diponegoro Semarang yang diambil secara consecutive sampling sebanyak 38 orang dan dibagi menjadi 2 kelompok secara simple random sampling. Kelompok perlakuan diberikan jus mentimun dan tomat $200 \mathrm{ml}$ selama 7 hari, sedangkan kelompok kontrol diberikan sirup 0 kalori. Pengukuran kadar glukosa postprandial dilakukan sebelum dan sesudah intervensi dengan metode spektrofotometri. Asupan makan subjek diperoleh dengan metode food recall 7x24 jam selama intevensi. Uji normalitas menggunakan Shapiro-Wilk. Analisis statistik menggunakan Independent Sample t-Test, Mann-Whitney, Paired t-Test dan Wilcoxon.

Hasil : Kelompok perlakuan mengalami penurunan kadar glukosa darah postprandial yang bermakna $(p=0,000)$ sebesar 3,32 $\pm 1,97 \mathrm{mg} / \mathrm{dl}$. Secara statistik terdapat perbedaan perubahan kadar glukosa darah postprandial antara kelompok perlakuan dan kontrol yang bermakna $(p=0,000)$.

Kesimpulan : Terdapat penurunan kadar glukosa darah postprandial yang bermakna setelah pemberian $200 \mathrm{ml}$ jus mentimun dan tomat selama 7 hari.
\end{abstract}

Kata Kunci : Mentimun, tomat, glukosa darah, perempuan overweight dan obesitas

\section{PENDAHULUAN}

Diabetes melitus (DM) merupakan penyakit sindrom metabolik dengan karakteristik hiperglikemia yang terjadi karena kelainan sekresi hormon insulin, kerja hormon insulin ataupun keduanya. Diabetes melitus dibagi menjadi 2 jenis, yaitu diabetes melitus tipe 1 (DMT1) terjadi karena sel $\beta$ pankreas yang memproduksi hormon insulin dalam tubuh tidak berfungsi dan hanya memproduksi sedikit hormon insulin atau bahkan tidak sama sekali. Diabetes melitus tipe 2 (DMT2) terjadi akibat kombinasi dari gangguan produksi hormon insulin dan resistensi insulin di membran sel tubuh. ${ }^{1}$ Pemeriksaan kadar glukosa darah postprandial menggambarkan penyerapan glukosa, sekresi insulin dan glukagon, metabolisme glukosa di dalam hati dan otot.

Prevalensi penderita DM di Indonesia 1,52,3 merupakan penduduk usia lebih dari 15 tahun. Berdasarkan Riskesdas 2013, prevalensi diabetes melitus meningkat dari 1,1\% (2007) menjadi 2,1\% (2013). ${ }^{2}$ Pada tahun 2011, jumlah penderita diabetes di kota Semarang mencapai 59.877 orang dengan jumlah DMT1 sebesar 23,9\% (14.326 orang) dan 
jumlah penderita DMT2 sebesar 76,1\% (45.551 orang). ${ }^{3}$

Overweight dan obesitas merupakan kondisi penumpukan lemak berlebih dalam tubuh. Overweight dan obesitas disebabkan adanya ketidakseimbangan antara asupan yang masuk dengan asupan yang keluar. Ketidakseimbangan antara asupan dengan energi yang dikeluarkan apabila terjadi dalam jangka waktu tertentu dapat mengakibatkan obesitas sentral. Obesitas sentral merupakan penumpukan lemak pada jaringan adiposa bagian abdomen. Obesitas sentral berkaitan dengan risiko terjadinya penyakit sindrom metabolik, diantaranya yaitu risiko penyakit DMT2. ${ }^{4}$ Pada perempuan risiko gangguan toleransi glukosa lebih tinggi dibandingkan laki-laki, hal tersebut dikarenakan komposisi lemak tubuh perempuan lebih tinggi dibandingkan dengan lakilaki. $^{5}$

Pencegahan peningkatan prevalensi diabetes melitus dapat dilakukan dengan pengaturan diet karena mampu mencegah kenaikan kadar glukosa darah dan menurunkan kadar glukosa darah. Makanan yang disarankan dalam pengaturan diet tersebut adalah makanan dengan indeks glikemik (IG) rendah, tinggi likopen dan magnesium $(\mathrm{Mg})$. Bahan makanan yang memiliki IG rendah, memiliki kandungan likopen dan $\mathrm{Mg}$ yang tinggi adalah tomat dan mentimun. ${ }^{6,7}$

Kandungan likopen pada tomat yang telah melalui proses pemanasan akan lebih banyak dan lebih mudah diserap tubuh dibandingkan dengan tomat segar. Kandungan likopen dalam $100 \mathrm{~g}$ tomat yang dibuat jus sebesar 12,8 mg sedangkan pada $100 \mathrm{~g}$ tomat segar sebanyak $5,8 \mathrm{mg} .{ }^{8}$ Penelitian tentang tomat yang digunakan sebanyak $180 \mathrm{~g}$ dengan kandungan likopen $23 \mathrm{~g}$ dapat menurunkan kadar glukosa darah sebesar $1,2 \mathrm{mg} / \mathrm{dl}$ pada penderita diabetes selama 3 hari. ${ }^{9}$ Kandungan $\mathrm{Mg}$ pada mentimun sebesar $11 \mathrm{mg}$. Pada penelitian mengenai efek antidiabetes polifenol terhadap kadar glukosa darah selama 21 hari menunjukkan penurunan kadar glukosa darah paling efektif pada hari ke-7. ${ }^{10}$ Penelitian mengenai pengaruh ekstrak hidroalkoholik dan buthanolik dari mentimun pada tikus wistar diabetes selama 9 hari menunjukkan ada penurunan kadar glukosa darah. ${ }^{11}$

Penelitian ini bertujuan untuk melihat pengaruh pemberian jus mentimun dan tomat terhadap kadar glukosa darah postprandial pada perempuan overweight dan obesitas.

\section{METODE}

Penelitian ini dilakukan di Program Studi Ilmu Gizi Fakultas Kedokteran Undip pada bulan
April-Mei 2015. Jenis penelitian adalah true experimental dengan rancangan pre-post group design. Penentuan subjek penelitian menggunakan metode consecutive sampling. Besar subjek dalam penelitian ini adalah 38 orang. Kriteria inklusi subjek antara lain berjenis kelamin perempuan, umur 18-24 tahun, IMT $\geq 23 \mathrm{~kg} / \mathrm{m}^{2}$, glukosa darah sewaktu (GDS) $\geq 90 \mathrm{mg} / \mathrm{dl}$, tidak mengonsumsi obat-obatan yang dapat mengendalikan glukosa darah selama penelitian, tidak dalam keadaan sakit, dan bersedia mengisi inform consent. Kriteria eksklusi adalah mengundurkan diri sebagai subjek penelitian dan tidak mematuhi prosedur penelitian.

Prosedur dalam penelitian ini dimulai dengan uji kandungan jus mentimun dan tomat yang terdiri dari uji kandungan energi, protein, lemak, karbohidrat, natrium, serat, kalium, magnesium dan indeks glikemik di Laboratorium Gizi dan Teknologi Pangan Universitas Muhammadiyah Semarang. Pengambilan data dalam penelitian ini dimulai dengan memberikan penjelasan tentang tujuan penelitian, metode, risiko dan ketidaknyamanan yang akan dialami serta keuntungan yang diperoleh sebagai subjek penelitian. Setelah itu peneliti menawarkan kesediaan menjadi subjek penelitian. Subjek yang telah bersedia dikumpulkan untuk dilakukan pengukuran berat badan, tinggi badan untuk mengetahui IMT (indeks massa tubuh), dan pengukuran GDS (glukosa darah sewaktu). Apabila subjek telah memenuhi kriteria, subjek diminta untuk menandatangani inform consent dan diberikan penjelasan lebih lanjut tentang penelitian. Sebanyak 38 subjek yang memenuhi kriteria inklusi dibagi menjadi dua kelompok menggunakan simple random sampling. Selanjutnya dilakukan pengambilan darah pre-test pada kelompok kontrol dan perlakuan untuk mengetahui kadar glukosa darah puasa (GDP) dan postprandial. Setelah dilakukan pengambilan GDP, subjek diberikan makanan kotak berupa $150 \mathrm{~g}$ nasi, 45 g sayur capcay dan $70 \mathrm{~g}$ galantin daging sapi dengan total beban glukosa sebanyak 49,35 g. Pada kelompok perlakuan diberikan jus mentimun dan tomat sebanyak $200 \mathrm{ml}$ selama 7 hari, sedangkan pada kelompok kontrol diberikan sirup 0 kalori sebanyak $200 \mathrm{ml}$. Setelah pemberian jus mentimun dan tomat selama 7 hari, pada hari ke-8 dilakukan pengambilan darah post-test pada kelompok kontrol dan perlakuan untuk mengetahui kadar glukosa darah puasa (GDP) dan postprandial.

Data yang dikumpulkan melalui wawancara adalah data umum subjek, asupan makan dan daya terima jus tomat dan mentimun. Data yang dikumpulkan melalui pengukuran 
antropometri adalah data berat badan melalui penimbangan dengan timbangan digital, tinggi badan melalui pengukuran dengan microtoise, dan data pengukuran glukosa darah sewaktu menggunakan alat glucometer. Variabel bebas pada penelitian ini adalah pemberian jus tomat dan mentimun. Jus mentimun dan tomat diproses dengan mencampurkan $100 \mathrm{~g}$ tomat, $100 \mathrm{~g}$ mentimun, $50 \mathrm{ml}$ air, dan sirup 0 kalori. Tomat diblanching terlebih dahulu selama 10 menit pada suhu $70-90^{\circ} \mathrm{C}$. Variabel terikat adalah kadar glukosa darah postprandial dengan satuan $\mathrm{mg} / \mathrm{dl}$. Subjek berpuasa selama $8-10$ jam lalu diberi makan kemudian diambil darah 2 jam setelah makan melalui pembuluh darah vena di lengan oleh petugas laboratorium. Variabel perancu adalah asupan energi, protein, lemak, karbohidrat, serat dan $\mathrm{Mg}$ yang diperoleh dengan menggunakan metode food recall $7 \times 24$ jam dan diolah menggunakan nutrisurvey.

Data yang diperoleh dianalisis secara statistik. Gambaran karakteristik subjek dianalisis dengan analisis deskriptif. Uji normalitas data menggunakan uji Shapiro-Wilk. Perbedaan kadar glukosa darah postprandial sebelum dan sesudah perlakuan pada kelompok perlakuan menggunakan uji Wilcoxon, sedangkan perbedaan kadar glukosa darah postprandial sebelum dan sesudah perlakuan pada kelompok kontrol menggunakan uji Paired $t$ test. Perbedaan penurunan kadar glukosa darah postprandial pada kelompok perlakuan dan kontrol dilakukan uji Mann-Whitney.

\section{HASIL}

Hasil skrining awal yang diikuti oleh 70 mahasiswa Program Studi Ilmu Gizi Fakultas Kedokteran Undip Semarang menunjukkan sebanyak 5 mahasiswa $(7,14 \%)$ memiliki status gizi normal, 20 mahasiswa $(28,57 \%)$ mengalami overweight dan 45 mahasiswa $(64,29 \%)$ mengalami obesitas. Dari jumlah tersebut, 41 mahasiswa $(58,57 \%)$ memiliki kadar glukosa darah sewaktu $(\mathrm{GDS}) \geq 90 \mathrm{mg} / \mathrm{dl}$.

\section{Penelitian Pendahuluan}

Penelitian pendahuluan dilakukan untuk menguji kandungan jus mentimun dan tomat yang terdiri dari energi, karbohidrat, protein, lemak, serat, natrium, kalium, magnesium dan indeks glikemik. Hasil uji kandungan nilai gizi jus yang terbuat dari $100 \mathrm{~g}$ mentimun, $100 \mathrm{~g}$ tomat, $50 \mathrm{ml}$ air dan sirup 0 kalori. Hasil uji kandungan jus mentimun dan tomat ditunjukkan pada tabel 1 .

Tabel 1. Kandungan Zat Gizi Jus Mentimun dan Tomat

\begin{tabular}{lc}
\hline \multicolumn{1}{c}{ Kandungan Gizi } & Jumlah \\
\hline Energi & $19,84 \mathrm{kkal}$ \\
Karbohidrat & $3,19 \mathrm{~g}$ \\
Protein & $1,24 \mathrm{~g}$ \\
Lemak & $0,31 \mathrm{~g}$ \\
Serat & $1,57 \mathrm{~g}$ \\
Natrium & $3,45 \mathrm{mg}$ \\
Kalium & $169,50 \mathrm{mg}$ \\
Magnesium & $16,77 \mathrm{mg}$ \\
Indeks Glikemik & 29 \\
\hline
\end{tabular}

Dari tabel 1, menunjukkan hasil bahwa dalam 200 $\mathrm{ml}$ jus mengandung $1,565 \mathrm{mg}$ serat; $16,765 \mathrm{mg}$ magnesium dan 29 indeks glikemik. Jus ini memiliki indeks glikemik rendah yaitu 29 sehingga dapat dikonsumsi subjek overweight dan obesitas.

\section{Karakteristik Subjek}

Karakteristik subjek yang terdiri dari status gizi dan kadar glukosa darah sewaktu (GDS) sebelum penelitian disajikan dalam tabel 2.

Tabel 2. Karakteristik Subjek

\begin{tabular}{|c|c|c|c|c|c|}
\hline \multirow{2}{*}{ Karakteristik Subjek } & \multicolumn{3}{|c|}{$\begin{array}{c}\text { Perlakuan } \\
(n=19)\end{array}$} & \multirow{2}{*}{$\begin{array}{c}\begin{array}{c}\text { Kontrol } \\
(n=19)\end{array} \\
\begin{array}{c}\text { Rerata } \pm S \\
\text { D }\end{array} \\
\end{array}$} & \multirow{2}{*}{$p$} \\
\hline & $\mathbf{n}$ & Rerata \pm SD & $\mathbf{n}$ & & \\
\hline Usia & & $20,05 \pm 1,18$ & & $20,79 \pm 1,32$ & 0,102 \\
\hline Status Gizi & & & & & \\
\hline Overweight $\left(23-24,9 \mathrm{~kg} / \mathrm{m}^{2}\right)$ & 7 & $26,00 \pm 2,30$ & 6 & $27,47 \pm 5,21$ & 0,746 \\
\hline Obesitas $\left(\geq 24 \mathrm{~kg} / \mathrm{m}^{2}\right)$ & 12 & & 13 & & \\
\hline GDS (mg/dl) & & $95,58 \pm 3,52$ & & $95,78 \pm 4,53$ & 0,837 \\
\hline
\end{tabular}

Uji beda Mann-Whitney 
Subjek dalam penelitian ini merupakan perempuan dengan usia antara 18-23 tahun dan sebagian besar subjek pada kelompok perlakuan maupun kontrol memiliki status gizi obesitas. Hasil uji beda terhadap usia, status gizi dan GDS antara kelompok perlakuan maupun kontrol menunjukkan tidak ada perbedaan antara kedua kelompok $(\mathrm{p}>0,05)$.

\section{Asupan Makan Selama Intervensi}

Data asupan makan selama intervensi disajikan pada tabel 3 untuk melihat rerata asupan makan subjek selama intervensi pada kelompok perlakuan dan kontrol.

Tabel 3. Asupan Makan Selama Intervensi

\begin{tabular}{lccc}
\hline & Perlakuan $(\mathbf{n}=\mathbf{1 9})$ & Kontrol $(\mathbf{n}=\mathbf{1 9})$ & \\
\cline { 2 - 3 } & Rerata \pm SD & Rerata \pm SD & \\
\hline Energi (kkal) & $1691,3 \pm 202,64$ & $1609,8 \pm 184,70$ & $0,203^{1}$ \\
Protein (g) & $61,57 \pm 1,32$ & $54,42 \pm 8,61$ & $0,056^{1}$ \\
Lemak (g) & $54,94 \pm 1,67$ & $52,97 \pm 2,16$ & $0,447^{2}$ \\
Karbohidrat (g) & $238,11 \pm 6,83$ & $240,95 \pm 6,47$ & $0,896^{1}$ \\
Serat (g) & $10,68 \pm 3,30$ & $10,15 \pm 3,07$ & $0,536^{2}$ \\
Magnesium (mg) & $200,21 \pm 2,42$ & $173,21 \pm 3,38$ & $0,002^{2}$ \\
\hline
\end{tabular}

${ }^{1} \mathrm{Uji}$ beda Independent t-test

${ }^{2}$ Uji beda Mann-Whitney

Berdasarkan hasil uji beda, tidak ada perbedaan asupan energi, protein, lemak, karbohidrat, dan serat antara kedua kelompok ( $>>0,05)$, namun terdapat perbedaan asupan magnesium dengan $p=0,002(p<0,05)$. Asupan $\mathrm{Mg}$ pada kelompok perlakuan lebih tinggi disebabkan oleh pemberian jus tomat dan mentimun selama intervensi.

Perbedaan Kadar Glukosa Darah Puasa dan Postprandial Sebelum dan Sesudah Intervensi

Tabel 4. Pengaruh Pemberian Jus Mentimun dan Tomat terhadap Kadar GDP dan Postprandial

\begin{tabular}{lccc}
\hline & $\begin{array}{c}\text { Perlakuan } \\
(\mathbf{n = 1 9 )}\end{array}$ & $\begin{array}{c}\text { Kontrol } \\
(\mathbf{n = 1 9 )}\end{array}$ & $\boldsymbol{P}^{\mathbf{3}}$ \\
\cline { 2 - 3 } & Rerata \pm SD & & \\
\hline GDP $(\mathrm{mg} / \mathrm{dl})$ & & & \\
$-\quad$ Pre-Test & $94,26 \pm 2,08$ & 0,005 \\
$-\quad$ Post-Test & $92,00 \pm 2,30$ & $94,05 \pm 2,37$ & \\
$-\quad \Delta$ & $-2,26 \pm 2,94$ & $94,31 \pm 2,31$ & \\
$-\quad p$ & $0,004^{1}$ & $0,26 \pm 2,92$ & \\
\hline Postprandial $(\mathrm{mg} / \mathrm{dl})$ & & $0,699^{2}$ & \\
$-\quad$ Pre-Test & $96,47 \pm 2,50$ & & \\
$-\quad$ Post-Test & $93,15 \pm 2,03$ & $93,89 \pm 2,44$ & \\
$-\quad \Delta$ & $-3,31 \pm 1,97$ & $93,68 \pm 2,62$ & \\
$-\quad p$ & $0,000^{1}$ & $-0,21 \pm 2,61$ & \\
\hline
\end{tabular}

${ }^{1}$ Uji beda Wilcoxon

${ }^{2}$ Uji beda Paired t-test

${ }^{3} \mathrm{Uji}$ beda Independent $t$-test

Hasil uji beda pada tabel 4 menunjukkan adanya perbedaan bermakna kadar glukosa darah puasa (GDP) dan postprandial sebelum dan sesudah perlakuan dengan $p=0,004$ dan $p=0,000(p<0,05)$, sedangkan perbedaan kadar glukosa darah puasa (GDP) dan postprandial pada kelompok kontrol tidak mengalami perubahan bermakna dengan $p=0,699$ dan $p=0,730(p>0,05)$.

Perbedaan rerata perubahan GDP dan postprandial antara dua kelompok dianalisis menggunakan uji Mann-Whitney menunjukkan perbedaan bermakna antara dua kelompok dengan $p=0,005$ dan $p=0,000(p<0,05)$.

\section{PEMBAHASAN}

Seluruh subjek dalam penelitian berjenis kelamin perempuan, karena kadarglukosa darah perempuan cenderung lebih tinggi dibandingkan laki-laki akibat perempuan memiliki komposisi lemak tubuh lebih tinggi dibandingkan dengan lakilaki sehingga lebih rentan mengalami kegemukan. ${ }^{5}$ Risiko menderita gangguan toleransi glukosa semakin meningkat seiring bertambahnya usia. Hal 
ini berkaitan dengan penurunan aktivitas fisik, perubahan komposisi tubuh, perubahan pola makan dan penurunan sensitivitas insulin.

Sebagian besar subjek pada penelitian memiliki status gizi obesitas $(65,79 \%)$. Obesitas merupakan faktor risiko terjadinya diabetes melitus. Persentase lemak tubuh yang berlebih dapat menyebabkan respon sel $\beta$ terhadap kadar glukosa darah menjadi berkurang, selain itu reseptor insulin pada sel target di seluruh tubuh menjadi kurang sensitif dan jumlahnya berkurang sehingga insulin dalam darah tidak dapat dimanfaatkan. ${ }^{4}$ Pemantauan terhadap kadar glukosa darah, asupan makan, dan aktivitas fisik juga diperlukan untuk menjaga kestabilan kadar glukosa darah.

Asupan makan berpengaruh terhadap kadar glukosa darah. Selama intervensi asupan makan kelompok perlakuan dan kontrol dipantau dengan food recall 7x24 jam. Tidak ada perbedaan asupan energi, protein, lemak, karbohidrat dan serat kelompok perlakuan dan kontrol $(p>0,05)$, sedangkan asupan $\mathrm{Mg}$ terdapat perbedaan antara kelompok perlakuan dan kontrol $(\mathrm{p}<0,05)$. Asupan $\mathrm{Mg}$ pada kelompok perlakuan lebih tinggi disebabkan pemberian jus mentimun dan tomat sebanyak $200 \mathrm{ml}$ selama 7 hari. Pengaturan pola makan merupakan salah satu cara efektif untuk menurunkan kadar glukosa darah.

Berdasarkan hasil uji statistik diketahui ada penurunan kadar glukosa darah postprandial yang bermakna pada kelompok perlakuan sebelum da sesudah intervensi. Hal ini menunjukkan ada pengaruh pemberian jus mentimun dan tomat sebanyak $200 \mathrm{ml}$ selama 7 hari pada kelompok perlakuan. Perbedaan kadar glukosa darah postprandial terjadi akibat adanya perbedaan asupan $\mathrm{Mg}$ antara kelompok perlakuan dan kontrol.

Penelitian terdahulu menunjukkan bahwa overweight dan obesitas terjadi penurunan sensitivitas insulin yang disebabkan adanya penebalan lapisan lemak viseral, sehingga kadar glukosa dalam darah tinggi. Penelitian kohort di China selama 8 tahun mengenai kejadian DMT2 dikaitkan dengan overweight dan obesitas menunjukkan bahwa kejadian DMT2 dengan perempuan overweight $(31,3 \%)$ lebih tinggi dari kejadian DMT2 dengan perempuan obesitas $(16,8 \%) .{ }^{4}$ Pada remaja obesitas memiliki serum $\mathrm{Mg}$ memiliki rerata $0,748 \mathrm{mmol} / \mathrm{dl}$ lebih rendah dibandingkan dengan status gizi normal dengan rerata $0,801 \mathrm{mmol} / \mathrm{dl}^{13}$ Magnesium dapat meningkatkan sensitivitas insulin. ${ }^{10}$ Sehingga risiko DMT2 pada status gizi obesitas lebih tinggi dibandingkan pada status gizi normal. ${ }^{13}$
Berdasarkan hasil uji laboratorium, kandungan $\mathrm{Mg}$ pada jus mentimun dan tomat sebesar $16,765 \mathrm{mg}$ lebih tinggi dibandingkan $100 \mathrm{~g}$ mentimun $(13 \mathrm{mg})$ dan $100 \mathrm{~g}$ tomat $(11 \mathrm{mg}) . \mathrm{Mg}$ merupakan kofaktor enzim pada metabolisme karbohidrat seperti pada aktivasi ATP-Mg kompleks yang dibutuhkan oleh semua enzim pada glikolisis, termasuk reaksi fosforilasi. Pada penelitian secara in vitro dan in vivo menunjukkan bahwa insulin mengatur perpindahan $\mathrm{Mg}$ dari ekstraseluler ke intraseluler. Konsentrasi $\mathrm{Mg}$ intraseluler juga telah terbukti efektif dalam proses modulasi insulin, terutama pada metabolisme oksidatif glukosa. Konsentrasi magnesium bebas intraseluler sangat penting dalam fosforilasi tirosinkinase pada reseptor insulin. Konsentrasi $\mathrm{Mg}$ intraseluler yang rendah, seperti pada pasien DMT2 dan hipertensi. ${ }^{7}$

Faktor lain yang mungkin dapat berpengaruh terhadap kadar glukosa darah postprandial dari asupan makanan tes postprandial seperti asupan energi, karbohidrat, lemak, protein serat, $\mathrm{Mg}$ dan total beban glikemik selama masa menunggu 2 jam pengambilan darah postprandial. Seluruh subjek diberikan makanan kotak untuk mengetahui respon glukosa darah postprandial berupa $150 \mathrm{~g}$ nasi, $45 \mathrm{~g}$ sayur capcay dan $70 \mathrm{~g}$ galantin daging sapi dengan total beban glikemik sebanyak 49,35 gram. Beban glikemik yang diberikan pada penelitian ini lebih rendah dibandingkan dengan tes toleransi glukosa oral (TTGO) yaitu $75 \mathrm{~g}$ (larutan berupa $75 \mathrm{~g}$ glukosa murni dan $330 \mathrm{cc}$ air). ${ }^{14}$ Meskipun adanya perbedaan beban glikemik yang diberikan pada penelitian ini tidak memperngaruhi hasil penelitian, dikarenakan beban glikemik yang diberikan untuk kelompok perlakuan dan kontrol sama.

Data pada food recall 7x24 jam selama intervensi menunjukkan asupan serat antara kelompok perlakuan lebih tinggi $(10,68 \mathrm{~g})$ dibandingkan dengan kontrol (10,15 g). Asupan serat dapat menurunkan kadar glukosa darah postprandial dengan tiga mekanisme, yaitu meningkatkan viskositas usus halus dan menghambat difusi glukosa, mengikat glukosa dan mengurangi konsentrasi glukosa dalam usus halus serta menghambat aksi $\alpha$-amilase. ${ }^{15}$ Serat pada tomat merupakan serat tidak larut yaitu hemiselulosa. ${ }^{16}$ Serat tidak larut mengurangi proses glukoneogenesis yang berpengaruh terhadap peningkatan sekresi insulin sehingga dapat mengurangi kenaikan kadar glukosa darah. ${ }^{17}$

Salah satu faktor yang menyebabkan jus mentimun dan tomat berperan dalam penurunan kadar glukosa darah postprandial adalah indeks 
glikemik yang rendah. Pencernaan karbohidrat dan penyerapan karbohidrat yang lambat menyebabkan penurunan produksi asam lemak bebas dan penurunan sekresi hormon kontra insulin (glukagon, steroid, tiroid dan katekolamin) sehingga mencegah hiperglikemia. Menurunnya produksi asam lemak bebas menyebabkan insulinisasi jaringan akan lebih efektif sehingga penggunaan glukosa oleh sel-sel perifer akan meningkat. ${ }^{18,19}$

Zat selain magnesium, serat dan indeks glikemik yang dapat berperan dalam menurunkan kadar glukosa darah postprandial yaitu likopen yang dalam penelitian ini tidak diteliti. Tomat yang digunakan dalam pembuatan jus merupakan tomat utuh dengan kulit yang mengalami proses blanching pada suhu $70-90^{\circ} \mathrm{C}$ selama 10 menit dengan tujuan meningkatkan kandungan likopen dalam tomat. Kandungan likopen pada $100 \mathrm{~g}$ tomat yang diblanching meningkat 2-2,5\% meningkat dibandingkan dengan likopen pada tomat segar. ${ }^{20}$ Likopen mampu melindungi kerja pankreas dari radikal bebas sehingga bekerja optimal dalam menghasilkan hormon insulin dan menurunkan resistensi insulin berakibat pada menyebabkan toleransi glukosa meningkat. ${ }^{21}$

\section{SIMPULAN}

Terdapat penurunan kadar glukosa darah postprandial yang bermakna sebesar $3,32 \mathrm{mg} / \mathrm{dl}$ setelah pemberian jus mentimun dan tomat sebanyak $200 \mathrm{ml}$ yang terdiri dari $100 \mathrm{~g}$ mentimun, $100 \mathrm{~g}$ tomat, $50 \mathrm{ml}$ air dan sirup 0 kalori selama 7 hari.

\section{DAFTAR PUSTAKA}

1. WHO. Diabetes Mellitus. (online) Available from URL:

http://www.who.int/topics/diabetes_mellitus/en. Accessed Mei 19, 2015

2. Riset Kesehatan Dasar (Riskesdas) 2013. Jakarta: Departemen Kesehatan Republik Indonesia. 2013

3. Dinas Kesehatan Kota (DKK) Semarang. Kasus Penyakit Tidak Menular di Puskesmas dan Rumah Sakit di Kota Semarang Tahun 2011. Semarang:DKK

4. Chao Wang, Jianxin Li, et al. Type 2 diabetes mellitus incidence in Chinese: Contributions of overweight and obesity. Elsevier Ireland 201; 107: 424-432

5. A.H. Zargar, S.R. Masoodi, B.A Laway, et al. Prevalence of overweight and obesity in young adults aged 20-40 years in North India (kashmir Valley). Diabetes Res. Clin. Pract. 87 (2010) e4-e6

6. Whitney E, Rolfes SR, Pinna K. Nutrition and Diabetes Mellitus. Dalam: Understanding Normal and Clinical Nutrition $7^{\text {th }}$ edition. Belmont: Wadsworth: 2002. Hal 790-816
7. Nizhizawa Y, Morii H, Durlach J. New Perpective in Mg Research Nutrition and Health. 2007. Hal 213223

8. Maulida D, Zulkarnaen N. Ekstraksi Antioksidan (Likopen) dari Buah Tomat dengan Menggunakan Solven Campuran, n-Heksana, Aseton, dan Etanol [Skripsi]. Jurusan Teknik Kimia, Fakultas Teknik, Universitas Diponegoro. 2010

9. Gartner C, Stahl W, Sies H. Lycopen is More Bioavailable from Tomato Paste than from Fresh Tomatoes. Am J Clin Nutr 2007;66:116-22

10. Bhoomika M, Raghunathan S, Porwal U. Cardioprotective effects of magnesium volproate in type 2 diabetes mellitus. European Journal of Pharmalogy 728 (2014); 128-134

11. Amalia F, Surialaga S, Rachmayati S. Effect of Cucumis sativus L on Glucose Absorption through Intestinal Mucosal Membrane of Wistar Rat Models. Althea Medical Journal 2014; 1 (1)

12. Milargos G, James N, et al. Mg Deficiency is Associated with Insulin Resistance in Obese Children. Diabetes Care, Volume 28, vol 5, Mei 2005. Hal 1175-1181

13. Koska. J, S. Nobert, AP. Paska, et al. Increased Fat Accumulation in Liver may link Insulin Resistance with Subcutaneous Abdominal Adipocyte Enlargement, Visceral Adiposity and Hypoadiponectinemia in Obese Individuals. $\mathrm{Am} \mathrm{J}$ Clin Nutr 2008; 87: hal 295-302

14. American Diabetes Association: Standards of Medicalcare in Diabetes (Position Statement). Diabetes Care 2005; 28 (Supplement I): S4-S36

15. Ou S, K Kin-Chor, Y Li and L Fu. In Vitro Study Possible Role of Dietary Fiber in Lowering Postprandial Serum Glucose. J Agric Food Chem, 2001; 49: 1026-1029

16. Nainggolan O, Adimunca C. Diet Sehat dengan Serat. Cermin Dunia Kedokteran. 2005 Vol. 51 No. 147

17. Perkumpulan Endokrinologi Indonesia. Konsensus Pengelolaan dan Pencegahan Diabetes Melitus Tipe 2 di Indonesia. Jakarta: PB. PERKENI; 2006. Hal 3-14, 30-31

18. Tjokorda Gde Dalem Pemayun. Indeks Glikemik. Kontroversi dalam Penanganan DM. Diabetes Melitus Ditinjau dari Berbagai Aspek Penyakit Dalam. Semarang: Badan Penerbit Undip (PERKENI): 2007. Hal 37-49

19. Donath MY, Shoelsen SE. Type 2 diabetes as an imflammatory disease. Nat Rev Immunol 2011; 11:98-107

20. Lu W, Simin L, Manson JE et al. The Consumption of Lycopene and Tomato-Based Food Product is Associated with the Risk of Type 2 Diabetes in Women. J Nutr 2006; 136: 620-625

21. Whitney E, Rolfes SR, Pinna K. Nutrition and Diabetes Mellitus. Dalam: Understanding Normal and Clinical Nutrition $7^{\text {th }}$ edition. Belmont: Wadsworth: 2002. Hal 790-816 